\title{
Teachers and students opinion regarding updated MBBS curriculum 2012 in a teaching hospital.
}

\author{
Badhon NM, ${ }^{1}$ Nahar $N,{ }^{2}$ Jahan I, ${ }^{3}$ Zaman $F,{ }^{4}$ Hossain $M I^{5}$
}

\begin{abstract}
The modern concept of a curriculum originally derived from the Latin word for a race course. Undergraduate medical education is part of a continuum of education and training. The new curriculum is structured to provide a balance among learning opportunities through integrated teaching system.

This study was carried out to explore the views of teachers and students regarding the current undergraduate medical curriculum.

This cross-sectional descriptive study was conducted between October 2019 to October 2020 among the teachers and students of a private medical college and hospital (MH Samorita medical collegesandhospital) in Dhaka Bangladesh. The sample size were 100 in total.

Most of the participants suggested for changes in overall existing MBBS curriculum. Highest satisfaction was seen in content related to learning objectives that were $90 \%$ and highest dissatisfaction was seen in Phase distribution of subjects that were $89 \%$. However, they were satisfied with present pattern of course content, objectives, evaluation system and carry on system. Teachers and students evaluation may prove useful if analyzed further to overcome the shortcomings of existing MBBS curriculum.
\end{abstract}

Keywords: MBBS Curriculum, Teachers, Students, Undergraduate.

1. Associate Professor, Department of Pharmacology and Therapeutics, MH Samorita Medical College, 117 Love road, Tejgaon, Dhaka

2. Professor and Head, Department of Pharmacology and Therapeutics, MH Samorita Medical College, 117 Love road, Tejgaon, Dhaka

3. Associate Professor, Department of Pharmacology and Therapeutics, MH Samorita Medical College, 117 Love road, Tejgaon, Dhaka

4. Associate Professor, Department of Anatomy, MH Samorita Medical College, 117 Love road, Tejgaon, Dhaka

5. Assistant Professor, Department of Pharmacology and Therapeutics, Rajshahi Medical College, Rajshahi

Address of correspondence: Dr. Nazia Mahmud Badhon, Associate Professor, Department of Pharmacology and Therapeutics, MH Samorita Medical College, 117 Love road, Tejgaon, Dhaka, Bangladesh. badhoncbmcb@gmail.com.

\section{Introduction}

The modern concept of a curriculum, originally derived from the Latin word for a race course, was first described in depth in a book by J. F. Bobbitt in the early twentiethcentury. ${ }^{1} \mathrm{~A}$ curriculum is a vision and a road map to meet the academic objective. Curriculum has been defined by Tanner and Tanner as 'The planned guided learning experience and intended learning outcomes formulated through a systematic reconstruction of knowledge and experiences under the auspices of school for the learner's continuous and willful growth in academic, personal and social competence'. ${ }^{2}$ The medical education system inherited the typical features of colonial education which is very much on

Bangladesh Journal of Medical Education 2022; 13(1); Badhon et al., publisher and licensee Association for Medical Education. This is an Open Access article which permits unrestricted noncommercial use, provided the original work is properly cited. 
the traditional pattern: lecture based, teacher centered, discipline based, examination oriented and hospital based. Before 1988 there was no formal medical curriculum except a syllabus which was published by Bangladesh medical \& Dental council. ${ }^{3}$ The national undergraduate medical curriculum adopted in medical colleges of Bangladesh was first developed in 1988 through Centre for Medical Education (CME) and supported by UNDP and WHO. The undergraduate medical curriculum followed in the medical colleges was developed with an aim to produce community oriented doctors who will be able to provide essential primary health care to the community. The process of medical education in Bangladesh began with the establishment of Mitford medical school and hospital Dhaka in the early 20 century. ${ }^{4}$

Undergraduate medical education is part of a continuum of education and training which continues through postgraduate training and continuing professional development. Such areas are often rendered to undergo widespread redesigning to fulfill the changing expectations of the society and the health professional themselves. ${ }^{5}$ Leading organizations in the field of medical education, for example the "Edinburgh Declaration" of World Federation for Medical Education (WFME) 3 and "Tomorrow's Doctors" by the General Medical Council (GMC) of UK, in their recommendations suggested the need for reorientation of medical education to cope with the continuously changing demands of the health care services. ${ }^{6}$

The new curriculum is structured to provide a balance among learning opportunities through integrated teaching system. Here the basic and clinical sciences are taught and learned together, enabling students to link their scientific knowledge with clinical experiences to support a good medical Bangladesh Journal of Medical Education 2022; 13(1); Badhon et al., publisher and licensee Association for Medical Education. This is an Open Access article which permits unrestricted noncommercial use, provided the original work is properly cited. 


\section{Result}

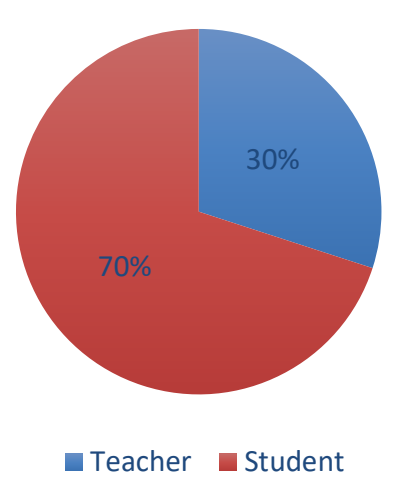

Figure-1: Categorical Distribution of Teacher and Student

Figure no. 1 showed the total of 100 questionnaires were distributed among the students and teachers respectively. Among them $70 \%$ students and $30 \%$ teachers responded.

Table I: Respondent's view about different aspects of existing curriculum

\begin{tabular}{|l|c|c|}
\hline \multicolumn{1}{|c}{ Comments } & Yes $(\%)$ & No(\%) \\
\hline Objectives seem reasonable with in time frame & $79 \%(79 \%)$ & $21 \%(21 \%)$ \\
\hline Content related to learning objectives & $90 \%(90 \%)$ & $10 \%(10 \%)$ \\
\hline Any content overload & $68 \%(68 \%)$ & $32 \%(32 \%)$ \\
\hline Teaching methods reasonable to teach the content & $60 \%(60 \%)$ & $40 \%(40 \%)$ \\
\hline Time reasonable to teach the content & $27 \%(27 \%)$ & $73 \%(73 \%)$ \\
\hline Phase distribution of subjects need reorientation & $89 \%(89 \%)$ & $11 \%(11 \%)$ \\
\hline Carry on system helpful for students & $78 \%(78 \%)$ & $22 \%(22 \%)$ \\
\hline Enough scope for problem based learning & $48 \%(48 \%)$ & $52 \%(52 \%)$ \\
\hline Reasonable scope for integration of subjects & $46 \%(46 \%)$ & $54 \%(54 \%)$ \\
\hline
\end{tabular}

Respondent's view about different aspects of existing curriculum are shown in table I. Regarding different aspects of the new curriculum, a major portion $(78 \%)$ were in favor of carry-on system. Most of participants were not satisfied with present course content, duration and phase distribution of subject. Highest satisfaction was seen in Content related to learning objectives that were $90 \%$ and highest dissatisfaction was seen in Phase distribution of subjects that were $89 \%$.

Bangladesh Journal of Medical Education 2022; 13(1); Badhon et al., publisher and licensee Association for Medical Education. This is an Open Access article which permits unrestricted noncommercial use, provided the original work is properly cited. 


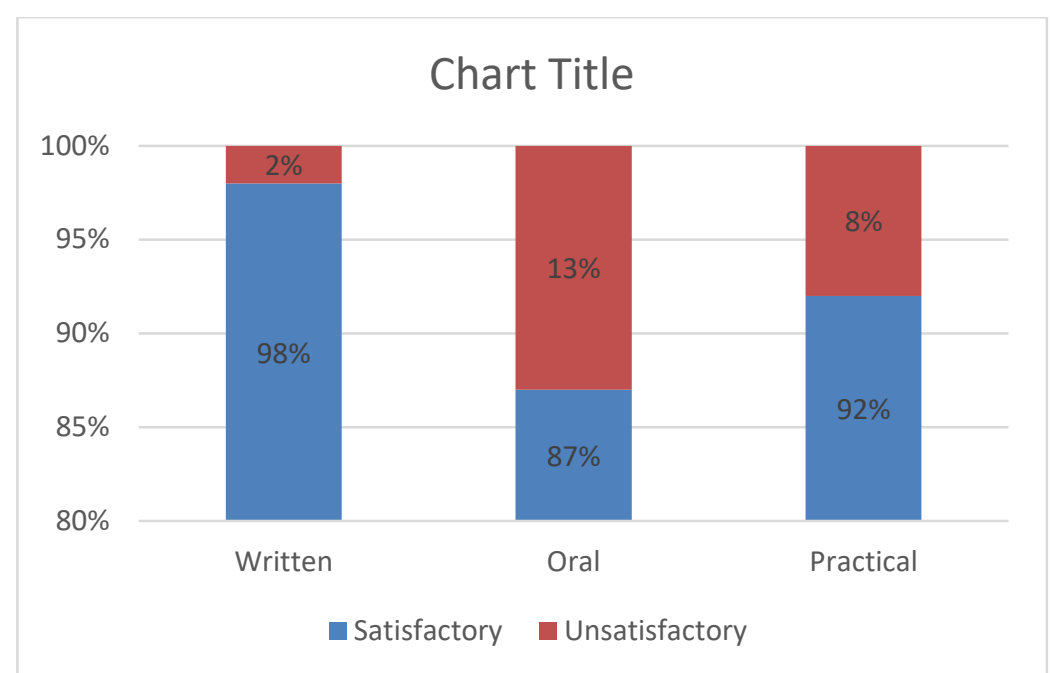

Figure 2: Percentage Wise Opinion on Examination System

The opinion on examination system is shown in figure 2. Most of participants were satisfied with every component of the written evaluation system (98\%). Here second position of participants were satisfied with practical evaluation system $(92 \%)$ and least satisfaction level in oral evaluation system that were $(87 \%)$.

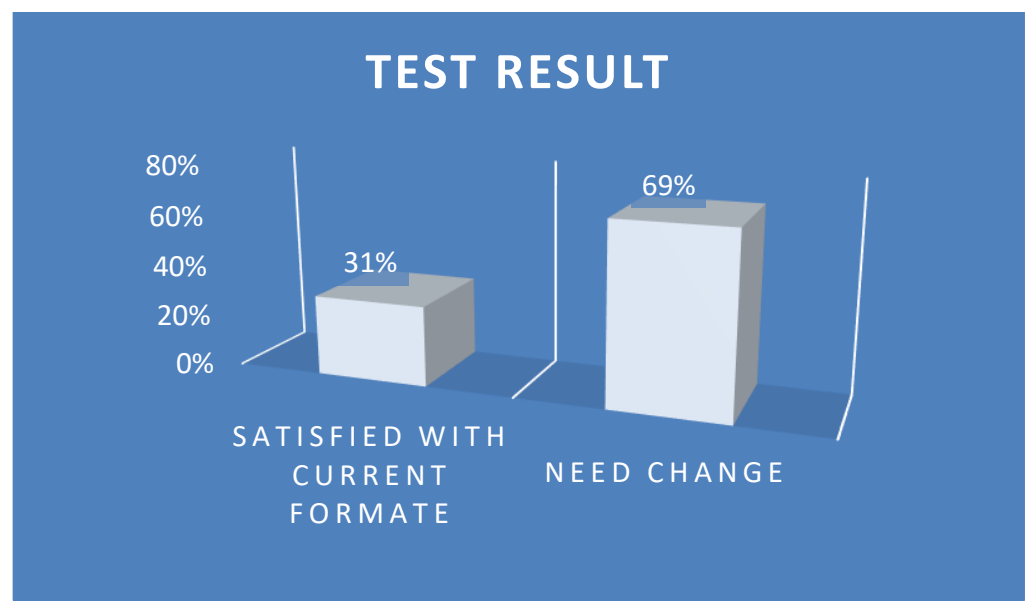

Figure 3: Percentage Wise Distribution of Respondent's Opinion about Change of this Curriculum

Figure no. 3 showed thatabout $69 \%$ of the respondents have asked for changes in the new MBBS curriculum. The ratio of satisfied vs need change were $31 \%$ vs $69 \%$, regarding modifications in every phase reasonably. Participants who wanted modification gave their valuable opinion upon phase wise subject distribution.

\begin{abstract}
Discussion
Evaluation of the existing teaching learning curriculum by the students is attempted in this study with an aim to focus on the necessary changes in the objectives, course contents or teaching methods in MBBS curriculum. Evaluation of teaching curriculum by teacher and students are firmly recommended as a part of teaching learning process and has been attempted by
\end{abstract}

Bangladesh Journal of Medical Education 2022; 13(1); Badhon et al., publisher and licensee Association for Medical Education. This is an Open Access article which permits unrestricted noncommercial use, provided the original work is properly cited. 
a number of educational researchers. Respondents opinions regarding revised 2012 MBBS curriculum where majority has recommended a number of changes.

Some important changes can improve our curriculum like: course content should be reduced, duration of course should be extended and re-arranged according to the weight of course contents like rearrangement of phase wise distribution of subjectsin terms of increased class number or hours, evaluation system should be revised, teaching-learning methods should be modified and made more problem based. Regarding phasewise subject distribution and examination system respondents gave many opinions but some major changes are necessary that are: Subjects should be rearranged as per phase duration, Teaching should be more practical oriented and better coordinated with subjects, lecture classes and word duties should be better coordinated, Classes in hospital wards should be more practical oriented, Incourse assessment (like card final, term final or ward final examinations) should be held timely and conducted properly.

Most of participants were satisfied with written evaluation system. It is divided into two part SAQ and MCQ. Some respondent's suggested that MCQ should be increase and number of SAQ should be decrease. Regarding oral examination majority were not in favor of present evaluation system. Those who were against the present evaluation system gave the following opinion: questions should be topic based, questions should be provided by a central examination committee to maintain equal weight and standard, enough time and effort should be applied to evaluate every student properly, teachers should be friendly during examination, question standard should be in accordance with the undergraduate curriculum. Regarding practical examination a number of different opinions came from the participants which is mixed with satisfactory and unsatisfactory response like: oral and practical examination should be held on separate dates, questions should be standard and supplied from central committee, laboratories of all concerned departments should be updated with modern equipments etc.

Our findings are the reflection of the teaching-learning experiences by the teachers and students. The MBBS curriculum of three neighboring countries we see, according to MBBS curriculum of Pakistan students get exposure of clinical cases after the $1^{\text {st }}$ professional examination by attending the lecture classes and ward placement. At the same time they used to learn Pharmacology, Forensic Medicine, Pathology and microbiology. ${ }^{8}$ In India, the MBBS course has been divided in 3 phases. Students were taught basic subjects in Phase I. They were devoted to Pathology, Community Medicine, Forensic Medicine, Pharmacology and Microbiology in Phase II. During this Phase clinical subjects were taught concurrently. ${ }^{9}$ In Sri Lanka basic subjects are taught in year 1 and 2 of their MBBS course. They used to learn Pathology, Microbiology, Pharmacology and Community Medicine in $3^{\text {rd }}$ and $4^{\text {th }}$ year. Teaching of clinical class begins from the $3^{\text {rd }}$ year and continued up to $5^{\text {th }}$ year. ${ }^{10} \mathrm{MBBS}$ curriculum of three neighboring countries (Pakistan, India and Sri Lanka) reveals that Pathology, Microbiology, Pharmacology and Community Medicine are taught at the beginning of clinical classes. In this study our students and teachers suggested that phase wise distribution of subjects need reorientation.

\section{Conclusions}

This study was carried out to explore teachers and students views regarding the

Bangladesh Journal of Medical Education 2022; 13(1); Badhon et al., publisher and licensee Association for Medical Education. This is an Open Access article which permits unrestricted noncommercial use, provided the original work is properly cited. 
present undergraduate 2012 MBBS curriculum in Bangladesh. There are positive and negative factors responsible for achieving desired competencies of the newly passed MBBS graduates. Moreover, the opinion of the basic science, paraclinical and clinical teachers and undergraduate MBBS students regarding for the further improvement of the under graduate MBBS curriculum. The study emphasized the areas of improvements in the curriculum as well as the institute and also need of change in the MBBS curriculum. The majority of the teachers and students were not satisfied on their acquired competencies in most of the areas after their graduation. This was due to shortage of course duration in comparison to number of subjects and contents, improper distributions of the subjects, less allocation of chances in problem based and integration of subjects etc.

\section{Reference}

1. Growth of the elective programme. Trends in the curriculum. The Centre for Medical Education, Sydney. P 4450-52
2. Bharvad AJ. Curriculum Evaluation. International Research Journal2010; 1(2): 1113.

3. Majumder MAA. Bangladesh Medical Journal 2003; 32: 37-39.

4. Hussain MM, Tlukder HK, Moazzem M, Rashid A, Hanif A, Nargis T. Evaluation of Existing Curriculum (2002) of Undergraduate Medical Education in Bangladesh. Mymensingh Medical Journal 2011; 20(2): 226-232.

5. Bleakley A, Brice J, Bligh J. Thinking the postcolonial in medical education Medical Education 2008; 42: 266-270.

6. World Federation for Medical Education. The Edinburgh Declaration. Med Edu 1988; 22:481-482.

7. Mosaddek ASM, Nargis W, Ahamed BU, Begum MF, Ara S, Rahman MF, Alim R, Jahan $F$, Parveen K. Evaluation of the Impact of Revised MBBS Curriculum: View of Intern Doctors, J ShaheedSuhrawardy med Coll. 2014;6(1): 21-23.

8. Curriculum of MBBS (Revised 2011), Pakistan Medical \& Dental Council and Higher Education Commission, Islamabad

9. MBBS degree course and Curriculum of Phase I and II Subjects - 2004, Rajiv Ghandhi University of Health Sciences, Karnataka.

10. Curriculum of MBBS course 2016, Faculty of Medicine and Allied Sciences, Rajarata University of Sri-Lanka, Mihintale.

Bangladesh Journal of Medical Education 2022; 13(1); Badhon et al., publisher and licensee Association for Medical Education. This is an Open Access article which permits unrestricted noncommercial use, provided the original work is properly cited. 